[Upsall, D. (2001). Teacher Accountability: Reflective Professional or Competent Practitioner? New Zealand Annual Review of Education, 10, 167-185]

\section{Teacher Accountability: Reflective Professional or Competent Practitioner?}

\section{DEBBY UPSALL}

\section{Abstract:}

Teacher accountability has been the focus of a series of Government reports and enactments over the past 15 years. This article argues that since the publication of Tomorrow's Schools, Government policy making has been dominated by a managerialist approach at odds with the priorities of many educationalists. The introduction of Performance Management Systems and Professional Standards has stressed competence in a series of observable behaviours, limiting creativity and lowering morale. Changing the focus to foster internal accountability would encourage teachers to be reflective professionals seeking to improve their own practices. Adequate resourcing in terms of both time and expertise is needed to ensure the dual purposes of professional development and management appraisal can both be attained.

A ccountability is one of the key tenets of contemporary education policy. It is a pervasive concept throughout the policy reforms of the post "Tomorrow's Schools" era. Initially the focus was on Board and whole school accountability, but over the past five years in particular, the focus has narrowed to scrutinise teacher practices. The issue of teacher accountability is not new, however. The 1986 Report on the Inquiry into the Quality of Teaching (Scott Report) stated, "the professionalism of teachers requires accountability" (p. 36), and "there is considerable public disquiet about the way current accountability procedures work" (p. 42).

An OECD report in 1988 (cited in Aiken, 1994, p. 1) described "the current growth of teacher appraisal schemes world-wide" as part of a general demand for accountability in the public sector. This trend is consistent with the thrust of the economic doctrines variously called "New Right" (Lauder, 1990), "economic rationalism" (Codd, 1999), "institutional economics" (Robertson, 1999) "New Public Management" (Thrupp, 1996) and "managerialism" (Sullivan, 1992), which influenced political thought strongly in the 80 s and 90 s. The Scott Report identified the quality of teaching as a "priority area of inquiry" because "it is the most important of all educational factors" (p. 8).

Public interest in the issue of teacher accountability, too, is always high. The media usually gives front-page coverage to reports of teacher misconduct and many Members of Parliament have stories of anxious parents complaining about unsatisfactory teachers. The issue is important to teachers because they want their profession to be valued. Most teachers entered the profession with a personal sense of vision or purpose. They accept the need for appraisal. In fact, Calder (1992) suggests that "any teacher trying to argue that there is no need for appraisal would be like a doctor trying to argue that there is no need for diagnosis"(p. 47). Teachers also recognise that incompetent teachers bring their profession into disrepute and accept the need for procedures to remove teachers who cannot or will not change unacceptable practices.

Finally, there's "the bottom line" - the Government invests hugely in its education system and needs assurances that it is getting value for money. With this background, it is not surprising that the Government took steps during the 1990s to introduce systems to make teachers more accountable. In this analysis of the issue of teacher accountability in New Zealand, I will discuss how a "managerialist" approach came to dominate Government policy making in education during this period, working against what many teachers saw as integral to their profession. I will examine the way policy was developed and the issues arising from this.

\section{Government Policy Background}

Successive governments have continued to acknowledge the importance of the issue of teacher accountability with a battery of working parties, committees, reports, reviews, guidelines and recommendations.

Even prior to the 1986 Scott Report, the 1976 Marshall Committee on the Registration and Discipline of Teachers made a number of recommendations that were never legally enacted. Whether this was due to opposition by the teacher organisations (Garlick, 1991, p. 32) or 
to some other factors, is unclear. Certainly at the time there was a very close relationship between teacher organisations and the Department of Education. Sullivan (1999) refers to this relationship as one of "trusted partners" sharing in the development of policy (p. 144). Treasury, however, regarded the closeness of this relationship with great suspicion. Its briefing paper, Government Management Volume II, Education Issues (1987) criticised what it described as the "provider capture" of education and recommended drastic changes.

Aiken (1994) comments that in Treasury's eyes professional selfregulation could be ruled out because "teachers could not be trusted" (p. 71). As an employee of the New Zealand Educational Institute Te Riu Roa (NZEI), the primary teachers' union, she reflected a teacher perspective in seeing the main thrust of the accountability debate as "anti-professional", favouring "market and managerial models in line with New Right thinking" (p. 15).

Administering for Excellence, the Report of the Taskforce to Review Educational Administration, more commonly known from its chairman as the Picot Report (1989), began with a vote of confidence in the "individual competence" of teachers (p. 4). However, it observed that "inevitably, interests have become vested in the existing structure" (p. 22) and "a highly centralised system is particularly vulnerable to the influence of pressure group politics" (p. 23). These statements echo Treasury's assertion that, "while many individuals will naturally seek to use their expertise to maximise quality, their representative interest groups will be concerned to protect their members' commitment to educational rather than other careers and to maximise their returns on such commitment" (p. 37).

The Picot committee was meeting during a time of flux in labour relations in New Zealand. The State Sector Act (1988) deregulated industrial relations, strengthening the move towards "the new management model". Capper and Munro (1990) commented, "This model sees most workplace decisions as being a management prerogative in which unions have no legitimate voice" (p. 152). Further evidence of this growing climate of managerialism came in 1989, when the State Services Commission (SSC) took over the role of negotiating as employer with the teacher unions. Aiken (1994) comments on the changes this brought to the negotiating table over the next few years.

... teacher salaries and conditions were set in an aggressive bargaining climate in which professional standards of teaching were no longer taken as unquestioned. In addition, the SSC attempted to shift the ground away from collegial models of working, including the professional model of appraisal, to a top-down, market management approach. (p. 77)

Picot's calls for more accountability in the education sector are understandable in this climate. However the structure of teacher appraisal proposed was claimed to be one "in which there are positive incentives to improve teacher performance", "taking place in a collaborative environment" with an emphasis on "developing strategies to improve (student's) learning outcomes" (p. 68).

The Government's response to the Picot Report, Tomorrow's Schools, accepted most of the Taskforce recommendations for the compulsory sector, and subsequently the Education Act (1989) was passed. This Act also established the Teacher Registration Board (TRB), with the main aims of maintaining a register of teachers and promoting a quality teaching profession. To achieve this it was to "assist schools in determining and appraising satisfactory standards of teacher performance" (TRB, 1996, p. 4). Also passed in 1989, the State Services Amendment Act provided for codes of conduct for teachers, giving Boards of Trustees power to prescribe their own standards, and giving the new Ministry of Education the right to "prescribe matters to be taken into account in assessing the performance of teachers" (cited in Aiken, 1994, pp. 77, 141)

In 1989 a Ministerial Working Party on Assessment for Better Learning, (also called Project ABLE), was asked to make recommendations on assessment procedures for the education system as a whole, including schools, teachers and students. Its report, Tomorrow's Standards (1990), considered the issue of teacher appraisal. It recommended keeping separate the formal assessment of teachers for management purposes from a process of ongoing peer appraisal for professional development (pp. 60-61).

The Lough Report (Today's Schools, 1990), focused on roles of school managers, principals and trustees, rather than teachers (Aiken, 1994, p. 80) but also recommended that a system be devised for assessing a school's educational outputs, based on national standards (Butterworth, 1997, p. 161). Furthermore, unlike Tomorrow's Standards, this report was couched in the language of the "New Right", using terms such as "key performance indicators". This reflected the Lough committee's composition; Lough himself was a former Treasury official and the committee included representatives of the SSC, Treasury and the business community. A new Government, a new Minister of Education 
and a more managerial approach to education issues was in ascendancy.

The Employment Contracts Act of 1991 continued the deregulation of labour started in the 1988 State Sector Act, further weakening the position of unions to negotiate on behalf of their members. During the collective employment contract negotiations in 1992, the teacher unions were forced to accept annual a ppraisal procedures determining primary principals' salaries within a range of rates, and certification of competence by principals as a prerequisite for teacher annual salary increments (Aiken, 1994, p. 78). Also during this period, the Ministry had a policy team working on the issue of teacher appraisal, which produced draft guidelines that were circulated in April 1992. They got no further, however, due to reservations expressed by the State Services Commission (Calder, 1992, p. 46; Aiken, 1994, p. 115).

The National Administration Guidelines (NAGs) were gazetted in April 1993. They required Boards of Trustees "to develop and implement personnel and industrial policies ... which promote high levels of staff performance", and to "be a good employer as defined in the State Sector Act 1988" (<www.minedu.govt.nz>). The State Sector Act defines a good employer as one who "operates a personnel policy containing ... opportunities for the enhancement of the abilities of individual employees ..." (Education Review Office, 1995, p. 10)

In 1995, the Education Review Office (ERO) expressed concern over the lack of progress schools were making towards establishing systems for managing staff performance (ERO, 1995, p. 24). It issued a report to schools, reminding Boards of Trustees of their obligations under the State Sector Act and the NAGs. It stated, " The devolution of greater management responsibility to individual schools in 1989 was accompanied by a greater demand for accountability to Government and the community. School-based evaluation and appraisal of staff, although not a specific requirement, became part of each board's responsibilities" (p. 8).

Chapman (2000) states that "the apparent lack of specificity regarding performance management during the early 1990s is consistent with the "hands off" policy that existed within the Ministry of Education during this period" (p. 45). This changed in 1995 when the Draft National Guidelines for Performance Management in Schools were published. During 1996, interest groups were invited to give feedback, and from January 1997, the revised guidelines were made mandatory. Schools were now required to institute a Performance Management System, defined by the Education Review Office as entailing "the recognition and support for effective teaching and management practices" (ERO, 1995, p. 5), but also "determining whether staff are performing to the standard expected by the employer" (p. 6). In order to do this, Boards would need to define "what knowledge, skills and abilities are essential for staff to have" (p. 6). Two agencies were trying to do just this. The TRB published its "Satisfactory Teacher dimensions" in 1997 and EROits "Capable Teacher core competencies" the following year.

The Government's desire to define "quality teaching" led it to undertake a review of teacher education in 1997. In the resulting Green Paper, Quality Teachers for Quality Learning: A Review of Teacher Education, the Minister of Education, the Hon. Wyatt Creech, reiterated his Government's belief in the significance of the issue of teacher quality. He wrote:

We want to see each and every young New Zealander participate fully and successfully in New Zealand society .... The teaching profession is responsible for effectively delivering this vision. The extent to which our education system succeeds ultimately depends on the quality of teaching in our classrooms. (p. 3)

The Green Paper went on to expound the need for nationally consistent "professional standards" to identify and define quality teaching, and a national professional body to promulgate them.

In the same year in which Quality Teachers was produced, the Chief Review Officer, Dr Judith Aitken, was raising teachers' ire with press statements claiming widespread teacher incompetence (Thrupp \& Smith, 1999, p. 190). A similarly aggressive stance was being shown by the SSC in the teachers' employment contract negotiations. In order to secure pay parity with secondary teachers, primary teachers were forced to accept a set of nationally formulated "Professional Standards" which were to be incorporated into schools' Performance Management Systems and be the criteria against which teachers were to be evaluated for salary progression. They were labelled "Interim" because of the expectation that a professional body for teachers would be established to review and ratify them.

The Post Primary Teachers' Association (PPTA) held out against professional standards for another year, maintaining "research findings were inconclusive as to the effectiveness of 'narrowly defined elements which purport to measure effective teaching'" (PPTA, 1999, cited in Chapman, 2000, p. 49), but finally conceded, after having gained some changes in scope and wording, along with significant salary increases. 
A further Government policy development on this issue was the Minister of Education's press release on July 23, 2000, regarding the proposed new Education Council. It was not a new idea. In 1993 a National Forum entitled "A New Zealand Teaching Council?" recommended the setting up of a standard-setting professional body, and the Teaching Council of Aotearoa came into being. It failed to gain sufficient support, however, and was defunct by 1997. The Green Paper Quality Teachers also proposed the establishment of a professional body for teachers to promulgate professional standards (1997, p. 26). Since then, the Ministry had been holding ongoing discussions with stakeholders to set up such a body. The July 23 announcement stated that the Education Council, replacing the TRB, would be established through legislation later in the year. It also signalled the Government's determination to keep the issue of teacher accountability on its agenda, stating that "processes for re-registration will be strengthened to better monitor teacher performance and behaviour" (Ministry of Education, 2000 , p. 1). The Minister invited interested parties to make submissions on the proposal. These were collated and analysed within the Ministry, and as of October, 2000, the proposal was back with the Minister.

Discussing just how performance management in schools is working, Chapman (2000) argues that it "has been made unnecessarily complex by the imposition of three different sets of requirements":

1. Compliance with the "satisfactory teacher" dimensions of the Teacher Registration Board for teacher registration and renewal of registration (TRB, 1997, p. 3);

2. Appraisal of the three "aspects" of teacher responsibilities in line with the Performance Management System requirements. (Education Gazette, February 10, 1997, p. 2);

3. Demonstration of performance against

- $\quad$ seven performance dimensions for primary teachers;

- $\quad$ nine performance dimensions for secondary teachers (Ministry of Education, 1999; NZEI, 1998, p. 5)

The proposed Education Council may be able to rationalise these confusing requirements, but even so the question must be asked: Does making teachers accountable by measuring them against a set of nationally determined standards really ensure teacher quality? Or has the Government's fixation on measurable, observable outcomes led it to equate defining teacher quality in terms of such outcomes with developing a quality teaching profession?

\section{What is "Quality Teaching"?}

The TRB "dimensions" define a "minimum level of acceptability" in a range of aspects of teaching, as required for teacher registration and renewal (1997, p. 2). However, minimum acceptability cannot be equated with quality teaching. The ERO stresses competence, but this competence must also be observable. "A competency is an observable behaviour which demonstrates that the person has the knowledge and skill required to do the job" (ERO, 1995, p. 6)

The danger of this approach to "render all work visible" is that it is de-professionalising (Codd, 1999, p. 52). It assumes that the central aspects of a teacher's work can be measured (Robertson, 1999, p. 129), and runs the risk of making teachers change practices not for educational reasons but just to "be seen to perform" (Whitty et al., 1998, p. 68) or because it will "look good for ERO" (Thrupp \& Smith, 1999, p. 195). Creative, diverse and innovative teaching practices are in danger of being lost. It is possible to tick off a list of competencies and still not have quality teaching. If teaching is viewed as a continuum from "poor quality" to "excellent quality", then ERO's competent practitioner would fall somewhere in the middle.

Poor quality

teaching

Excellent quality teaching

$<\frac{1}{\begin{array}{c}\text { ERO's competent } \\ \text { practitioner }\end{array}}>$

MacGilchrist et al. (1997) define effective teaching as "not a fixed set of skills and knowledge but ... constantly evolving and adapting to the needs of different groups of pupils ... a continuous process" (p. 54). Fish (1991, cited in Horsburgh, 1994, pp. 117, 122) also emphasises the on-going aspect of teacher professionalism, defining teachers as "human beings who are still learning to be teachers" and who keep on learning throughout their professional lives. John Stephenson, of Leeds University (1997), contrasts competence, which he defines as the ability to deal with familiar situations, with capability, the ability to deal with the unknown. "Staying capable in a world of change requires confidence in one's ability to manage one's own learning" (p. 9).

I would argue that reflection is the key. A quality teacher critically reflects on his/her practice and continually seeks opportunities to update and improve. A very effective teacher could be described as a 
"reflective professional", and placed towards the right of the continuum diagrammed below.

Poor quality

teaching

$<$

Excellent quality eaching

\section{ERO's competent}

practitioner

\section{A reflective}

professional

For a long time teachers have resisted the development of a set of professional standards, believing that writing down what was expected of a teacher would limit innovation, creativity and diversity, reducing teachers to technicians pursuing competence rather than excellence. The managerial model encourages this "ticking the boxes" mentality, requiring teachers to focus on observable, measurable outputs such as records and work-plans. But MacGilchrist et al. put it well when they say, "We must learn to measure what we value rather than valuing what we can easily measure" (1997, p. 3).

One dimension of the Professional Standards which has resulted in much worthwhile discussion and professional development for primary school teachers is the area of professional knowledge about the Treaty of Waitangi. A beginning teacher is required to "understand the implications of the Treaty of Waitangi and te reo me ona tikanga"; a fully registered teacher is required to "demonstrate knowledge of the Treaty of Waitangi and te reo me ona tikanga"; and experienced teachers are required to "demonstrate commitment to their ongoing learning" (Ministry of Education, 1998, p. 19). However, when the NZEI called for compulsory training of all teachers in "te reo me ona tikanga", at its September, 2000 annual conference, it failed to gain the support of the Minister of Education (Hamilton, 2000, p. 2). If the Government is really serious about "closing the gap", whether or not it chooses to use this particular term, more must be done to enable mainstream schools (which cater for $85 \%$ of Maori students) to reflect "te reo me ona tikanga" in their everyday practices. Otherwise the New Zealand education system will continue to be "operated in breach of the Treaty" (Treaty of Waitangi Tribunal, 1996).

\section{Policy Issues and Questions}

Is it really possible to measure effective teaching? Does the use of standards of external accountability in fact impede the Government's stated purpose of improving teacher quality?

Codd's "Contradictory discourses of educational evaluation" (Codd, 1994) provide useful models for discussing this issue. ERO's emphasis on "competence" and the Ministry's pursuit of a definition of quality teaching in terms of a list of specific criteria against which teacher performance will be measured (the Professional Standards) epitomise Codd's "Technocratic-reductionist" discourse. The opposing "Professional-contextualist" view emphasises critical self-evaluation and the process rather than the product, "enabling the emergence of unanticipated outcomes and the development of diverse human capabilities such as creativity, imagination and critical thinking" (p. 51).

Codd (1999) believes that a focus on external forms of accountability, using the Professional Standards to measure performance through systems of formal recording and reporting of information, reflects a "culture of distrust" (p. 52). He argues for a change in direction, one that would replace the current low-trust, externally imposed managerial focus with one that promotes professional responsibility, collegial trust and internal motivation. ${ }^{2}$

O'Neill (1997) too, decries the focus on individual accountability as detracting from collegial support and collective responsibility models of teaching. He promotes the "reflective professional" model:

I can engage in focused talk with colleagues in order to find out why they and I teach in the ways that we do. Together, we can question, explore possibilities and ... analyse our practice, experiment and develop new areas of skill and awareness. This process takes encouragement, empathy, time, trust, energy and resources. Performance Management in Schools delivers none of these. The mandatory requirements are obsessed with individual accountability. (p. ii)

Insisting that a teacher prove competence through observable behaviours can have a negative effect on teaching practice. Thrupp and Smith (1999) believe that a focus on "this will be good for ERO" has resulted in teachers adopting

... practices which can demonstrate "value-added" even if elaborate and of dubious value .... They seem to be spending considerably more time in the production and maintenance of records and less 
time engaged in more creative, diverse and reflective teaching. (p. 195)

Future policy makers would do well to consider these arguments if they are serious about improving teacher quality.

A second issue concerns the design of the appraisal process.

\section{Is it possible to combine both managerial and professional development} purposes in the one process?

Tomorrow's Standards, the report of the Ministerial Working Party on Assessment for Better Learning, recommended keeping separate the formal assessment of teachers for management purposes from a process of ongoing peer appraisal for professional development (pp.60-61). This distinction reflects two distinct types of evaluation: summative and formative.

In her analysis of teacher appraisal practices in New Zealand, Aiken (1994) describes these approaches in terms of two opposing models. An accountability model uses summative evaluation and seeks to rank teachers, rating them against a fixed scale for the purposes of comparing them, eliminating incompetent teachers and rewarding those performing well. A professional development model uses formative evaluation, seeking to pinpoint strengths and weaknesses and identify areas for development with the purpose of making better teachers. She argues that these two contrasting models cannot be combined successfully (pp. 27-41).

The same issue has been debated overseas. American researchers Wise, Darling-Hammond et al. (1985, cited in Garlick, 1991, p. 10), questioned whether a single evaluation system could handle both formative and summative purposes after making a comprehensive study of teacher appraisal systems in their country.

In the United Kingdom in 1989, the National Steering Group (NSG) on teacher appraisal supported a process of formative appraisal that could lead to some summative decisions such as writing references, re-assignment of duties and providing information in the event of disciplinary procedures (Garlick, 1991).

In Australia, Scriven (1989) contrasts "enriched" systems of teacher evaluation with "basic" systems. A basic system is purely summative, generating information for personnel decisions. An enriched system has, in addition, a support system aimed at teacher improvement, involving formative evaluation. It provides recommendations and resources for remediation or improvement. Scriven, however, sees the summative aspect of teacher evaluation as more important than the formative aspect:

While it is true that enriched systems are to be preferred ... there are two aims for teacher evaluation systems and the position taken here is that the primary one is the summative one; the icing on the cake is the formative one. If you cannot tell whether someone is in trouble or not, which is the job of the summative system, you certainly cannot make suggestions for improvement. (p. 96)

Scriven goes on to propose a "Duties-Based Approach" identifying nine dimensions of teacher performance to be evaluated.

Garlick (1991), writing on teacher appraisal in New Zealand, concluded that, "Staff development and procedures to deal with incompetent teachers are the two main appraisal purposes to which I give highest priority, and I believe they are able to be carried out within the one scheme"(p. 72). She advocated using the TRB's "satisfactory teacher dimensions" in a system similar to Scriven's "Duties Based Approach". This is a similar approach to that adopted by New Zealand six years later with its Professional Standards.

When it introduced performance management into New Zealand schools, the Ministry of Education took the view that both accountability and professional development purposes could be catered for in the one system.

Collins (1997), a former member of the performance management development group within the Ministry of Education, acknowledges the tension between the two purposes of performance appraisal regarding the principal's role. As both the professional leader of the school and its chief executive officer, the principal has responsibility to "provide informed assurance to the Board about the overall quality of teaching in the school" (p. 11), confirm "satisfactory teacher" status for ongoing registration, attest to salary progression, and where necessary, institute competency procedures. If information from the appraisal process is not kept separate and confidential, Collins warns of the danger of "guardedness, window-dressing and teacher withdrawal" (p. 12). Would teachers reveal their self-perceived shortcomings to an appraiser if they believed this information could be used to decide their future employment, salary increase or promotion chances? If the purpose of teacher appraisal is to improve the quality of teaching, teacher trust, cooperation and honesty are essential. Collins argues for 
a "Two Stage Option", in which the two processes are kept separate initially, but in time, when the people involved have gained sufficient confidence and experience, become integrated into one.

However, Bailey, a school principal, believes that mixing the purposes of professional development and management appraisal is "a recipe for disaster" (1997, p. 19). His school has developed three separate systems for performance appraisal: self appraisal with peer support to identify professional development needs; appraisal by senior management for quality assurance purposes, incorporating evaluation of performance against key performance areas as stipulated in the National Guidelines; and thirdly, appraisal by the principal where needed for salary increment. A system as complex as this, however, involves a huge commitment by both the principal and the staff, in both time and energy.

Chapman illustrated the alternatives in what she termed her "fan" model for performance management (2000, pp. 55-56). The dual purposes of teacher appraisal are represented by the two "axes" of a fan. When the "fan" is open, the assessment (accountability) and the appraisal (professional development) processes are separate and distinct. When the "fan" is closed, these two purposes are combined in one process. As Chapman states, "One integrated system may be less costly in terms of time, but if the price includes a reduction in teacher commitment to the process then the employer may consider the cost to be too high" (pp. 56). However she suggests that compromises between these two extremes are possible - for example, using data from an observation of teaching for both assessment and appraisal purposes.

The importance to the reflective professional of opportunities for professional development cannot be over-emphasised. Munro (1989) states, "The only form of teacher appraisal likely to prevent unnecessary stress and concealment on the one hand, or window-dressing on the other, is peer appraisal among teachers themselves" (p. 35). As Southworth (1987, cited in Bailey, 1991, p. 15) reasoned, "Teacher appraisal should provide opportunities for teachers to talk about and share their concerns and reflections on their teaching. Essentially, the nature and effectiveness of appraisal rests on the quality of the relationships that exist in the school."

A peer appraisal scheme that enables reflection, self-analysis and the identification of areas of need for professional development is essential. However, this could only succeed if teachers were assured that the information would not be used "against" them. Any system of accountability for management purposes would need to be kept quite separate.

The most obvious policy implications for Government revolve around the need for adequate resourcing, both in time and expertise, to ensure that the dual purposes of performance appraisal can be achieved. Schools are asking," Where will the time to do the job properly come from?", "How will the need for on-going training/skilled personnel be met?", and "How will the increased need for professional development be funded?"

There is a third significant issue:

Teacher suspicions as to the "real" agenda behind the implementation of Performance Monitoring Systems and Teacher Professional Standards.

Many educationists believe that the managerial thrust of the reforms in education over the past decade have led increasingly to the commodification of education. ERO's "shame and blame" approach (Thrupp \& Smith, 1999, p. 188) and Treasury's pursuance of "the fully funded option" have fostered a climate of distrust and the suspicion that "performance linked pay" is to follow. Links between pay and performance appraisal were foreshadowed in the Quality Teachers Green Paper (1997). ERO (1995) states plainly that Boards could include rewards or incentives in their performance management systems (p. 6). The rationale behind performance-linked pay is simple - individuals who believe their pay to be directly related to their performance will work harder.

But solid evidence in relation to the teaching force is lacking. Codd (1994) argues that behind his two contrasting discourses of evaluation lie different assumptions about human nature. Are teachers motivated by extrinsic rewards or intrinsic factors? Sullivan (1994) also takes up this theme in his description of teachers' "implicit contract". "When teachers are trusted and supported in their jobs, they take on responsibilities much wider in scope than those prescribed in any explicit work contract" (p. 3). He believes that the more autonomy teachers have, the more highly motivated they will be. This reflects Herzberg's theory of motivation in the workplace (cited in Jones, 1994, p. 156) - "workers derive satisfaction from work that is meaningful and which they have a stake in organising and controlling."

However, according to Lauder, the "New Right" view of human nature is that people are "fundamentally concerned with the pursuit of self-interest and ... the acquisition of wealth, status and power" (1990, 
p. 4). This view is reflected in the comments about teachers made by the Secretary for Education, Howard Fancy, and cited by Sullivan (1999) "higher pay would mean a higher level of input into school life"(p. 146). His belief in the advantages of performance-related pay for teachers has resulted in teachers' salaries being linked to the Professional Standards.

This is despite the conclusion of a Government commissioned study by Deloitte Touche Tomatsu (1994) - "The evidence clearly indicates that it will not improve the quality of teaching and learning in schools, nor will it enhance morale within the teaching workforce. Every indication is that it will, in fact, negatively impact on morale" (p. 32).

Other studies have reached the same conclusion (Annesley, 1992, cited in Sullivan, 1999; OECD, 1998, cited in Aiken, 1994, p. 80). Wells (1989) observes that in recent years, most plans for merit pay in the United States of America have collapsed, leaving it operating in only about four percent of school districts. She concludes, "On the basis of American experience, attempts to use financial rewards to improve teaching performance almost inevitably fail" (p. 29). It is therefore not surprising that moves by the New Zealand Government to introduce performance-related pay have met with strong opposition.

\section{Conclusion}

This article has outlined how a "managerial" focus has driven the issue of teacher accountability away from a collaborative, supportive and positive model aimed at improving teacher quality, towards one that stresses competence in a series of prescribed observable behaviours. I believe that the result of this focus is likely to be a loss of creativity and innovation in the classroom and a lowering of teacher morale.

I have suggested that in order to ensure "quality" teaching in our classrooms, teachers need opportunities for self-reflection, peer appraisal and professional development targeted to their needs. Measuring teachers against a set of Professional Standards does not ensure a quality teaching profession, and may even in fact have the opposite effect.

Performance Management Systems that attempt to combine both managerial and professional development objectives in the one process run the risk of losing teacher trust and commitment. A dual system is to be preferred, but even this must ensure that the developmental aspects are valued. Overseas research and comment has shown that performance pay does not work in schools, and any government pursuing this concept would be demonstrating adherence to an unsupported theory. If the New Zealand Government desires to maximise its investment in its teachers, a change in focus is necessary. It should aim to build a culture of trust, promoting diversity, and encouraging teachers to become truly "reflective professionals".

\section{Notes}

1. Cited by W. Penetito, EDUC 502 class, Victoria University of Wellington, August 26, 2000

2. It is interesting to note that the corporate world is moving away from a hierarchical low trust model towards one which gives its employees more autonomy and less structure, in an attempt to foster internal motivation. (Holmes, TV1, October 3, 2000)

\section{References}

Aiken, S. (1994). Appraisal: A process of control or development? Unpublished Masters thesis, Victoria University of Wellington, Wellington.

Annesley, B. (1997). Performance indicators for New Zealand schools: The problems and the potential. New Zealand Annual Review of Education, 6, 105-126.

Bailey, H. (1997). Doing appraisal. In J. O'Neill (Ed.), Teacher appraisal in New Zealand (pp. 17-46). Palmerston North: ERDC Press.

Bailey, J. (1991). Appraisal: Linking appraisal and professional development in schools. Hamilton: Waikato Education Centre, University of Waikato.

Butterworth, G., \& Butterworth, S. (1997). Reforming education: The New Zealand experience 1984-1996. Palmerston North: Dunmore Press.

Calder, I. (1992). Monitoring today's schools. Report no. 8: Staff development and teacher appraisal. Hamilton: University of Waikato.

Capper, P., \& Munro, R. (1990). Professionals or workers? Changing teachers' conditions of service. In S. Middleton, J. Codd, A. Jones (Eds.), New Zealand education policy today: Critical perspectives (pp. 150-160). Wellington: Allen and Unwin.

Chapman, T. (2000). Managing teacher performance in today's schools. New Zealand Annual Review of Education, 9, 43-61.

Codd, J. (1994). Educational reform and the contradictory discourses of evaluation. Evaluation and Research in Education, 8(1), 41-53. 
Codd, J. (1999). Educational reform, accountability and the culture of distrust. New Zealand Journal of Educational Studies, 34(1), 45-54.

Collins, G. (1997). Performance management: Development and implimentation issues. In J. O'Neill (Ed.), Teacher appraisal in New Zealand (pp. 1-16). Palmerston North: ERDC Press.

Deloitte Touche Tohmatsu. (1994). Report of the working group on primary teachers' pay, performance and accountability.

Department of Education. (1988). Administering for excellence: Effective administration in New Zealand. (Picot Report). Wellington: Government Printer.

Department of Education. (1988). Tomorrow's schools: The reform of education administration in New Zealand. Wellington: Government Printer.

Education Review Office. (1998). The capable teacher. $<$ http://www.ero.govt.nz>

Education Review Office. (1995). Managing staff performance in schools. Wellington: ERO.

Fancy, H. (1997). Prescribing performance appraisal. The New Zealand Gazette, 76(2). Wellington: Learning Media.

Garlick, M. (1991). Teacher appraisal within the New Zealand reform of education administration. Unpublished Master of Public Policy research paper, Victoria University of Wellington, Wellington.

Hamilton, P. (2000, September 28). Compulsory Maori in too hard basket. Evening Post, p. 2.

Horsburgh, M.(1994, May). Valuing teaching. Paper presented to New Zealand Qualifications Authority Conference, Wellington.

Lauder, H. (1990). The New Right revolution and education in New Zealand. In S. Middleton, J. Codd, \& A. Jones, A. (Eds.), New Zealand education policy today: Critical perspectives (pp. 1-26). Wellington: Allen and Unwin.

MacGilchrist, B., Myers, K., and Reed, J. (1997). The intelligent school. London: Paul Chapman Publishing.

Minister of Education. (1998). A report on the compulsory school sector in 1997. Wellington: Ministry of Education.

Ministry of Education (1990). Tomorrow's Standards: The Report of the Ministerial Working Party on Assessment for Better Learning. Wellington: Learning Media.
Ministry of Education. (1997). Quality teachers for quality learning: A review of teacher education. Wellington: Ministry of Education.

Ministry of Education (1998). Teacher performance management: Primary school teachers, primary school deputy/assistant principals. Wellington: Ministry of Education,

Ministry of Education. (1999). Professional standards: Criteria for Quality teaching. Wellington: Ministry of Education.

Ministry of Education. (2000). Websites <www.edcouncil.govt.nz $>$, $<$ www.minedu.govt.nz/teacher/review97>.

Munro, R. (1989). The Munro report: Research into the personnel provisions of Tomorrow's Schools. Wellington: New Zealand Post-Primary Teachers' Association.

Neville, M. (1997). Equity in performance appraisal: A contradiction in terms. In J. O'Neill (Ed.), Teacher appraisal in New Zealand (pp. 81-97). Palmerston North: ERDC Press.

New Zealand Educational Institute Te Riu Roa. (1998). Implementing professional standards. Wellington: NZEI.

New Zealand Government. (1986). Report of the Education and Science Select Committee: The quality of teaching (Scott Report).Wellington: Government Printer.

O'Neill, J. (Ed.). (1997). Teacher appraisal in New Zealand. Palmerston North: ERDC Press.

Scriven, M. (1989). The state of the art in teacher evaluation. In J. Lokan \& P. McKenzie (Eds.), Teacher appraisal: Issues and approaches (pp. 92-137). Hawthorn: Australian Council for Educational Research.

Stephenson, J. (1997). Beyond competence to capability: The rise of the autonomous learner. In K. McKay \& J. Heinrich. (Eds.), Capability, educating for life and work (pp. 8-13). Wellington: Education and Training Support Agency.

Sullivan, K. (1993). The myth of partnership: Educational reform and teacher disempowerment. New Zealand Annual Review of Education, 2, 151-165.

Sullivan, K. (1994). The impact of educational reform on teacher's professional ideologies. New Zealand Journal of Educational Studies, 29(1), 3-20. 
Sullivan, K. (1999). Teacher standards and professionalism: Contested perspectives in a decade of reform. New Zealand Journal of Educational Studies, 34(1), 144-155.

Teacher Registration Board. (1993). A New Zealand Teaching Council? A National Forum. Conference papers, Wellington.

Teacher Registration Board. (1996). A statement of intent. Wellington.

Teacher Registration Board. (1997). A satisfactory teacher and renewing a practising certificate. Wellington.

Thrupp, M. (Ed.) (1999). Special Issue: A Decade of Reform in New Zealand Education. New Zealand Journal of Educational Studies, 34(1).

Thrupp, M., \& Smith, R. (1999). A Decade of ERO. In Thrupp, M. (Ed.), Special Issue: A Decade of Reform in New Zealand Education. New Zealand Journal of Educational Studies, 34(1), 186-198.

The Treasury. (1987). Government Management: Brief to the Incoming Government: Volume II. Education Issues. Wellington: Government Printer.

Wells, P. (1989). Policy Developments in the United States of America. In J. Lokan \& P. McKenzie (Eds.), Teacher appraisal: Issues and approaches (pp. 25-32). Hawthorn: Australian Council for Educational Research.

Whitty, G., Power, S., \& Halpin, D. (1998). Devolution in education: The school, the state, and the market. Camberwell, Victoria: Australian Council for Educational Research.

\section{The author}

Debby Upsall is a permanent part-time teacher at the Correspondence School in Wellington. She is also studying part-time to complete her MEd at Victoria and raising a son, aged 4 . For the past 7 years Debby has been working primarily with Special Needs children, both teaching at a distance and writing resources to send to them. Her teaching background includes intermediate schools, an area school, a small rural school and teaching English for a year in Japan. 